\title{
High sensitivity C-reactive protein as a predictive of intima-media thickness in patients with end-stage renal disease on regular hemodialysis
}

This article was published in the following Dove Press journal: International Journal of General Medicine

\author{
Lestariningsih Lestariningsih ${ }^{\prime}$ \\ Suharyo Hardisaputro ${ }^{2}$ \\ Ayudyah Nurani ${ }^{1}$ \\ Damai Santosa ${ }^{3}$ \\ Gunawan Santoso 4 \\ 'Division of Nephrology, Department of \\ Internal Medicine, School of Medicine, \\ Diponegoro University/Dr. Kariadi \\ Hospital, Semarang, Indonesia; ${ }^{2}$ Division \\ of Tropic Infection, Department of \\ Internal Medicine, School of Medicine, \\ Diponegoro University, Semarang, \\ Indonesia; ${ }^{3}$ Division of Hematology \\ Medical Oncology, Department of \\ Internal Medicine, School of Medicine, \\ Diponegoro University/Dr. Kariadi \\ Hospital, Semarang, Indonesia; \\ ${ }^{4}$ Department of Radiology, School of \\ Medicine, Diponegoro University/Dr. \\ Kariadi Hospital, Semarang, Indonesia
}

Correspondence: Damai Santosa Division of Hematology Medical Oncology, Department of Internal Medicine, School of Medicine, Diponegoro University/Dr. Kariadi Hospital, Jl. Dr. Soetomo No 16, Semarang, Indonesia

Email petrisemarang@yahoo.com
Background: Several emerging problems of regular hemodialysis (HD) including cardiovascular complication or atherosclerosis formation caused by chronic inflammation. Intimamedia thickness (IMT) of the carotid artery can be applied as a marker of atherosclerosis progression. This study was designed to identify the predictive of IMT progression among end-stage renal disease (ESRD) subject.

Methods: This cohort study was performed at the Hemodialysis Unit of Dr. Kariadi Hospital and Telogorejo Hospital Semarang between October 2009 and April 2010. The study subjects were the ESRD patients with regular HD.

Results: This study enrolled 78 subjects with regular HD, follow-up 6 months. The subjects which completed the study were divided into two groups that consist of IMT progressive group ( $n=53)$ and IMT non-progressive group $(n=12)$. There were no differences between two groups according to age, gender, history of diabetes, blood pressure, duration of HD, urea, creatinine, blood glucose, HbA1C, cholesterol, triglyceride, HDL, uric acid, phosphate, calcium, homocysteine, and albumin. Subject with high-sensitive C-reactive protein (hsCRP) level $>0.52 \mathrm{mg} / \mathrm{L}$ had an IMT progression. There was a correlation between hsCRP and the thickening of carotid artery wall after 6-month $\mathrm{HD}(\mathrm{RR}=3.6 ; 95 \% \mathrm{CI}=2.2-22.9)$. The subject with hsCRP level $>9.00 \mathrm{mg} / \mathrm{L}$ after 6 -month dialysis progress to thickening of carotid artery wall of $>0.03 \mathrm{~mm}$. There was a correlation between hsCRP level (cut-off point: $9.0 \mathrm{~m} / \mathrm{L}$ ) and the progression of the carotid artery wall $(\mathrm{RR}=2.1 ; 95 \% \mathrm{CI}=1.3-3.37)$. Statistically, there was no correlation between IL-6-174 G/C gene and eNOS gene polymorphism with IMT progression.

Conclusion: hsCRP is a significant predictive of IMT progression at hemodialysis subject. IL $-174 \mathrm{G} / \mathrm{C}$ gene and eNOS gene polymorphism are not significant predictive of IMT progression at hemodialysis subject.

Keywords: hemodialysis, atherosclerosis, IMT, hsCRP

\section{Introduction}

Patients on chronic hemodialysis are at greater risk of morbidity and mortality as compared with the general populations. ${ }^{1-4}$ Among the several associated factors of atherosclerosis, more attention has been given to the contribution of inflammation and its consequence in hemodialysis patients. ${ }^{1}$

The study in Japan population revealed that high levels of high sensitive C-reactive protein (hsCRP) were predictive of chronic kidney disease (CKD) for women. $^{5}$ The association between hsCRP and progression of early carotid 
atherosclerosis shows sex differences. ${ }^{6}$ There is an independent relationship between hsCRP and both intimamedia thickness (IMT) and ankle-brachial index (ABI) as measures of subclinical atherosclerosis. ${ }^{7}$ In patients with stages 2-5 CKD, high serum IL-6 is associated with a history of cardiovascular disease (CVD) and predicts incident cardiovascular $(\mathrm{CV})$ events. ${ }^{8}$ The genotype at the IL-6 to $-174 \mathrm{G} / \mathrm{C}$ polymorphism is associated with common carotid artery IMT. ${ }^{9}$ Higher concentrations of IL-6 among those with the GG genotype are associated with increased plasma concentrations of fibrinogen and CRP. ${ }^{10}$ As a result of decreased eNOS level, nitric oxide (NO) level decreased on endothelial dysfunction. ${ }^{11}$ Expression of gene eNOS-894T polymorphism reported a play role on decreased eNOS level. ${ }^{12}$

Inflammation exposure in hemodialysis is supposed due to the type of atherosclerosis progression. ${ }^{13}$ Carotid IMT study and endothelial adhesion molecules in the foreign general population reported that the risk of myocardial infarction increased in IMT value $>0.82 \mathrm{~mm}$ $(0.82-1.2 \mathrm{~mm}){ }^{14}$ Study of atherosclerosis risk in the community (ARIC) reported that IMT value increases $0.01 \mathrm{~mm} /$ year in the hypertension population. ${ }^{15}$ There are not study that evaluated IMT progression associated with hsCRP, eNOS gene polymorphism, and IL -174 G/C gene polymorphism in the Indonesian population.

\section{Methods}

This cohort study was conducted during sixth month in the Hemodialysis Unit, Dr. Kariadi Hospital and Telogorejo Hospital, Indonesia. The subjects which completed the study were divided into two groups that consist of IMT progressive group $(n=53)$ and IMT non-progressive group $(n=12)$ as measure of IMT. The study was approved by the Ethical Committee of the Faculty of Medicine, Diponegoro University and Dr. Kariadi Hospital (Ethical Number: 6 6/EC/FK/RSDK/2010). All subjects were given information regarding this study and signed the informed consent. This study was conducted in accordance with the Declaration of Helsinki.

The enrollment criteria were age 18-70 years, creatinine clearance $<15 \mathrm{~mL} / \mathrm{min}$ (the Cockcroft-Gault formula), endstage renal disease subject on regular hemodialysis, hemodialysis $>3$ months in a stable condition, routine hemodialysis, the period of hemodialysis $4 \mathrm{hrs}$, twice a week. The exclusion criteria were (1) subject with acute and chronic infections that are determined based on the presence of leukocytosis in peripheral blood images, (2) subject with chronic diseases including tuberculosis, hepatitis, and diabetes with injuries that are receiving treatment, (3) have active autoimmune disease, (4) get non-steroid anti-inflammatory drugs, (5) subject with history of stroke.

Complete blood count was measured by flow cytometry method (Cell-Dyn Saphire; Abbott Diagnostics Division, Santa Clara, CA, USA). Serum creatinine $(\mathrm{Cr})$, uric acid (UA), high-density lipoprotein (HDL), lowdensity lipoprotein (LDL), lactate dehydrogenase (LDH), blood glucose (BG), HbA1C, and Ox-LDL were measured by the enzymatic method (TMS, Tokyo Boeki Machinery LTD, Japan). Homocysteine was measured by immunoassay method (IMX immunology analyzer, Ensefal Medica Prima, Jakarta, Indonesia). IL-6 level was measured using the human IL-6 immunoassay method (Quantikine ${ }^{\circledR}$ HS Elisa kit; R\&D Systems, Inc., Minneapolis, MN, USA). Plasma levels of hs-CRP were measured by the particleenhanced immunoturbidimetric method (TMS, Tokyo Boeki Machinery LTD, Japan).

IMT was measured by two radiologists at carotid arteries by B-mode USG (LOGIQ Ultrasound system, GE Healthcare P6, 2010, type 55,011) at Department of Radiology, Dr. Kariadi Hospital Semarang. Delta of IMT was determined based on changes in IMT from the beginning of the study to after 6 months of HD. The progressive IMT was defined if the delta IMT $\geq 0.03 \mathrm{~mm}$. Blood pressure was classified according to 7 th JNC. Diagnosis of diabetes was defined by the Criteria of the American Diabetes Association.

\section{Sample collection and DNA extraction}

DNA extraction from blood used QIAmp DNA mini kit protocol (Qiagen, UK). Isolate of DNA was kept in the deep freezer $\left(-80^{\circ} \mathrm{C}\right)$ until measurement of genotyping. The $\mathrm{G} / \mathrm{C}$ polymorphism at position -174 of the interleukin-6 gene was typed by polymerase chain reaction (PCR) amplification using primer pairs 5'CACTCCACCTG GAGACGCCT3' and 5'TCCCTCACACAGGGCTCGA C3' under standard conditions using $2 \mathrm{mM} \mathrm{MgCl}_{2}$, followed by restriction digestion with NlaIII and agarose gel electrophoresis.

\section{Data analysis}

Fisher exact test or Chi-square test was used to compare the nominal data between two groups. Mann-Whitney test was used to compare median data between two groups. 
Discriminant analysis was used to classify the progressive and non-progressive group according to level IL-6 and hsCRP. The predictive factor to progression IMT was analyzed used Fisher exact test. Two-sided $p \leq 0.05$ was considered as statistically significant. These data were analyzed by IBS SPPS Version 22 .

\section{Result}

The participant rate at re-examination was $83.33 \%$. Table 1 shows the baseline characteristics of the study population. The mean age was $49.8(\mathrm{SD} \pm 10.48)$ years. The duration of $\mathrm{HD}$ was $2.2(\mathrm{SD} \pm 2.7)$ months. Mostly, the subject had no history of DM, edema, and ascites. The level of glucose, cholesterol, triglyceride, and HDL was mostly normal.

After 6-month follow-up, the subjects which completed the study $(\mathrm{n}=65)$ were classified into the IMT progressive group $(\mathrm{n}=53 ; 81.5 \%)$ and IMT non-progressive group $(\mathrm{n}=12 ; 18.5 \%) \quad$ (Table 2). There were no differences between two groups according to age, gender, history of diabetes, blood pressure, duration of HD, urea, creatinine, blood glucose, HbA1C, cholesterol, triglyceride, HDL, uric acid, phosphate, calcium, homocysteine, and albumin.

The discriminant analysis was done to distinguish the subjects into the progressive and non-progressive group according to hsCRP and IL levels (Table 3). The Canonical Discriminant Function Coefficients of IL-6 and hsCRP were 0.6 and 0.8 , respectively. There was a correlation between IMT and low levels of hsCRP (coefficient correlation $=0.31 ; p=0.01$ ). Correlations between IMT and levels of IL-6 were low (coefficient correlation $=0.36 ; p=0.003$ ). The canonical discriminant function coefficients of hsCRP were higher than IL-6. hsCRP level can be used to classify the progressive and nonprogressive group significantly.

ROC analysis of hsCRP showed that the area under curve was $0.76(p=0.006)$. This showed that hsCRP levels at the beginning of the study can be used to predict an increase in IMT after 6 months of HD. In these ROC analyses, it was also known that the hsCRP cut-off point for the thickening of IMT was $0.52 \mathrm{mg} / \mathrm{L}$. The area under the ROC curve of the hsCRP level to predict the occurrence of wall thickening a. internal carotid $>0.03 \mathrm{~mm}$ in 6 months HD was 0.67 . This showed that hsCRP with cutoff point 0.9 can be used to predict progression $>0.03 \mathrm{~mm}$.

Table 4 shows that subject with hsCRP level $>0.52 \mathrm{mg} /$ $\mathrm{L}$ has an IMT progression, but not at the subject with hsCRP levels $\leq 0.52 \mathrm{mg} / \mathrm{L}$. There was a correlation between hsCRP and the progression of carotid artery
Table I Characteristic and history of the study population

\begin{tabular}{|c|c|c|}
\hline Variable & Mean (SD) & $n=78(\%)$ \\
\hline Age (year) & $49.8 \pm 10.5$ & \\
\hline $\begin{array}{l}\text { Sex } \\
\text { - Man } \\
\text { - Woman }\end{array}$ & & $\begin{array}{l}58(74.4) \\
20(25.6)\end{array}$ \\
\hline Duration of HD (year) & $2.2 \pm 2.7$ & \\
\hline $\begin{array}{l}\text { History of diabetes mellitus } \\
\text { - Yes } \\
\text { - No }\end{array}$ & & $\begin{array}{l}15(19.2) \\
63(80.8)\end{array}$ \\
\hline $\begin{array}{l}\text { History of edema } \\
\text { - yes } \\
\text { - no }\end{array}$ & & $\begin{array}{l}3(3.8) \\
75(96.2)\end{array}$ \\
\hline $\begin{array}{l}\text { History of ascites } \\
\text { - Yes } \\
\text { - No }\end{array}$ & & $\begin{array}{l}10(12.8) \\
68(87.2)\end{array}$ \\
\hline $\begin{array}{l}\text { Glucose level }(\mathrm{mg} / \mathrm{dL}) \\
>126 \\
\leq 126\end{array}$ & & $\begin{array}{l}22(28.2) \\
56(71.8)\end{array}$ \\
\hline Cholesterol (mg/dL) & $|43.9 \pm 3| .4$ & \\
\hline $\begin{array}{l}\text { Cholesterol level }(\mathrm{mg} / \mathrm{dL}) \\
>200 \\
\leq 200\end{array}$ & & $\begin{array}{l}3(3.8) \\
75(96.2)\end{array}$ \\
\hline Triglyceride (mg/dL) & $|23.7 \pm 6| .7$ & \\
\hline $\begin{array}{l}\text { Triglyceride level }(\mathrm{mg} / \mathrm{dL}) \\
>150 \\
\leq 150 \mathrm{mg} / \mathrm{dL} \\
\text { HDL }(\mathrm{mg} / \mathrm{dL}) \\
\text { HDL level } \\
>35 \mathrm{mg} / \mathrm{dL} \\
\leq 35 \mathrm{mg} / \mathrm{dL}\end{array}$ & $32.3 \pm 10.1$ & $\begin{array}{l}16(20.5) \\
62(79.5) \\
51(65.4) \\
27(34.6)\end{array}$ \\
\hline
\end{tabular}

Abbreviations: $H D$, hemodialysis; HDL, high-density lipoprotein.

wall after 6-month dialysis ( $\mathrm{RR}=3.6 ; 95 \% \mathrm{CI}=2.2-22.9)$. The subject with hsCRP levels $>0.50 \mathrm{mg} / \mathrm{L}$ has a risk to develop the IMT progression of 3.6 times. The subject with hsCRP level $>9.0 \mathrm{mg} / \mathrm{L}$ after 6 -month dialysis progress to carotid artery wall $>0.03 \mathrm{~mm}$. There was a correlation between hsCRP (cut-off point $=9.0 \mathrm{mg} / \mathrm{L}$ ) and the progression of the carotid artery wall $(\mathrm{RR}=2.1$; $95 \% \mathrm{CI}=1.3-3.37)$. The subject with levels of hsCRP $>0.9$ has risk progression of artery wall 2.1 times.

PCR analysis showed 3 subjects (4.65\%) with IL-6 $-174 \mathrm{G} / \mathrm{C}$ gene polymorphism and 15 subjects $(23.1 \%)$ with eNOS gene polymorphism. The subject only has a single polymorphism gene, no subject with double gene polymorphism. Three subjects have IL-6 $-174 \mathrm{G} / \mathrm{C}$ gene 
Table 2 Factors that affect the IMT in progressive and non-progressive

\begin{tabular}{|c|c|c|c|}
\hline \multirow[t]{2}{*}{ Variable } & \multicolumn{2}{|l|}{ IMT classification } & \multirow[t]{2}{*}{$\mathbf{P}$} \\
\hline & Progressive $(n=53)$ & Non-progressive $(n=\mid 2)$ & \\
\hline Age (year) & $50.1 \pm 10.5$ & $49.2 \pm 12.9$ & $0.80^{\circ}$ \\
\hline \multicolumn{4}{|l|}{ Gender } \\
\hline - Male & $42(64.6 \%)$ & $10(15.4 \%)$ & \\
\hline - Female & II (I6.9\%) & $2(3.1 \%)$ & $1.00^{¥}$ \\
\hline \multicolumn{4}{|l|}{ History of diabetes; n (\%) } \\
\hline - Yes & II (I4.1\%) & $2(2.6 \%)$ & \\
\hline - No & $53(64.6 \%)$ & $12(18.5 \%)$ & $0.40^{¥}$ \\
\hline \multicolumn{4}{|l|}{ Blood pressure; n (\%) } \\
\hline - Normal & $6(9.2 \%)$ & $0(0.0 \%)$ & \\
\hline - Borderline & $13(20.0 \%)$ & $3(4.6 \%)$ & \\
\hline - Hypertension & $34(52.3 \%)$ & $9(13.8 \%)$ & $0.50^{\S}$ \\
\hline Duration of HD (month) & $18(6.5-30.0)$ & $12(6.6-25.3)$ & $0.64 *$ \\
\hline Urea pre HD (mg/dL) & $147(|26.3-| 73 . I)$ & $152(\mid 16.0-199.6)$ & $0.87^{*}$ \\
\hline Urea post $\mathrm{HD}(\mathrm{mg} / \mathrm{dL})$ & $57.0(44.3-78.6)$ & $58(47.0-57.0)$ & $0.97 *$ \\
\hline Creatinine pre HD (mg/dL) & $14.0(11.7-100.8)$ & $16.8(\mid 1.4-134.0)$ & $0.54 *$ \\
\hline Creatinine post $\mathrm{HD}(\mathrm{mg} / \mathrm{dL})$ & $5.7 \pm 1.85$ & $5.9 \pm 1.70$ & $0.80^{\circ}$ \\
\hline URR (\%) & $62.5(55.5-66.7)$ & $63.0(57.0-67.0)$ & $0.69 *$ \\
\hline Blood Glucose (mg/dL) & $96.0(88.3-120.3)$ & $108(88.0-146.0)$ & $0.19 *$ \\
\hline $\mathrm{HbAIC}(\%)$ & $5.7(52 .-5.9)$ & $5.5(5.0-6.0)$ & $0.92 *$ \\
\hline Cholesterol (mg/dL) & $145.6 \pm 29.4$ & $152.0 \pm 38.5$ & $0.50^{\circ}$ \\
\hline Triglyceride (mg/dL) & $\mid \mathrm{I} 0.5(96.5-\mid 42.5)$ & $103(85.0-159.0)$ & $0.69 *$ \\
\hline $\mathrm{HDL}(\mathrm{mg} / \mathrm{dL})$ & $32.0(27.5-38.0)$ & $30(26.0-40.0)$ & $0.67^{*}$ \\
\hline Uric acid (mg/dL) & $7.9 \pm 2.6$ & $8.0 \pm 1.6$ & $0.90^{\circ}$ \\
\hline Phosphate (mmol/L) & $6.1 \pm 2.2$ & $5.3 \pm 1.2$ & $0.20^{\circ}$ \\
\hline Calcium (mmol/L) & $8.8 \pm 0.8$ & $8.6 \pm 0.5$ & $0.40^{\circ}$ \\
\hline Homocystein $(\mu \mathrm{mol} / \mathrm{L})$ & $23.9(19.4-29.9)$ & $23.5(|8.7-3| .7)$ & $0.97^{*}$ \\
\hline Albumin (gr/dL) & $3.6(3,4-4,2)$ & $3.9(3,3-4,5)$ & $0.50 *$ \\
\hline IL-6 (pg/mL) & $2.98(0.9-7.0)$ & $10.32(1.1-59.2)$ & $0.03 *$ \\
\hline $\mathrm{hs}-\mathrm{CRP}(\mathrm{mg} / \mathrm{L})$ & $1.99(0.4-7.1)$ & $11.03(0.2-59.9)$ & $0.006 *$ \\
\hline
\end{tabular}

Notes: ${ }^{¥}$ Fisher exact test, ${ }^{\S} \mathrm{Chi}$-square test, ${ }^{\infty}$ Unpaired $t$-test, $*$ Mann-Whitney test (median, interquartile).

Abbreviations: URR, urea reduction ratio; HD, hemodialysis; IMT, intima-media thickness.

polymorphism, and two subjects have IMT progression. Statistically, there was no correlation between polymorphism IL-6-174 G/C gene and the eNOS gene with the progression of IMT.

\section{Discussion}

In this study, the majority of ESRD HD patients $(81.5 \%)$ were categorized as progressive IMT. Szeto et al (2007) reported the same result in the Chinese population with a lower incidence of $59.6 \%{ }^{13}$ The mean age on progressive group subjects was $51 \pm 9.3$ years old which is older than on non-progressive group $49.3 \pm 12.9$ years old. Hojs et al (2003) reported that cardiovascular mortality in ESRD patients was 10-20 times higher than in the general population. ${ }^{16}$ Most of the progressive group had a history of diabetes $(16.9 \%)$ with normal HbA1C. In the progressive group, the level of pre-dialysis area was higher than the non-progressive group. Uremia is an additive risk factor in those subjects who have raised carotid IMT. ${ }^{17}$ The prevalence of diabetes mellitus in productive age urban Indonesians was $4.6 \%$, consisting of $1.1 \%$ previously diagnosed diabetes mellitus and 3.5\% undiagnosed diabetes mellitus. ${ }^{18}$

Discriminant analysis showed the only hsCRP could be used to classify into the progressive and non-progressive groups. The subject with levels of hsCRP $>0.9$ has risk progression of artery wall 2.1 times. Another study showed that hsCRP levels of $\geq 2.0 \mathrm{mg} / \mathrm{L}$ were associated with increased IMT, plaque burden, and plaque echoluscency in carotid arteries. hsCRP levels $\geq 2.0 \mathrm{mg} / \mathrm{L}$ were accompanied by elevated IMT in the carotid bulbs independently of other cardiovascular risk factors. ${ }^{19}$ 
Table 3 The discriminant analysis to classify the progressive and non-progressive group

\begin{tabular}{|c|c|c|c|}
\hline Variable & $\begin{array}{l}\text { Canonical } \\
\text { Discriminant } \\
\text { Function } \\
\text { Coefficients }\end{array}$ & $\begin{array}{l}\text { Wilks } \\
\text { Lambda }\end{array}$ & $\begin{array}{l}\text { Percentage case } \\
\text { with right } \\
\text { classification }\end{array}$ \\
\hline $\begin{array}{l}\text { hsCRP } \\
\text { (mg/L) } \\
\text { IL-6 (pg/ } \\
\mathrm{mL})\end{array}$ & $\begin{array}{l}0.8 \\
0.6\end{array}$ & $\begin{array}{l}0.936 \\
(p=0.04) \\
0.957 \\
(p=0.98)\end{array}$ & $61.5 \%$ \\
\hline
\end{tabular}

Table 4 The risk factor for IMT progression in the study population

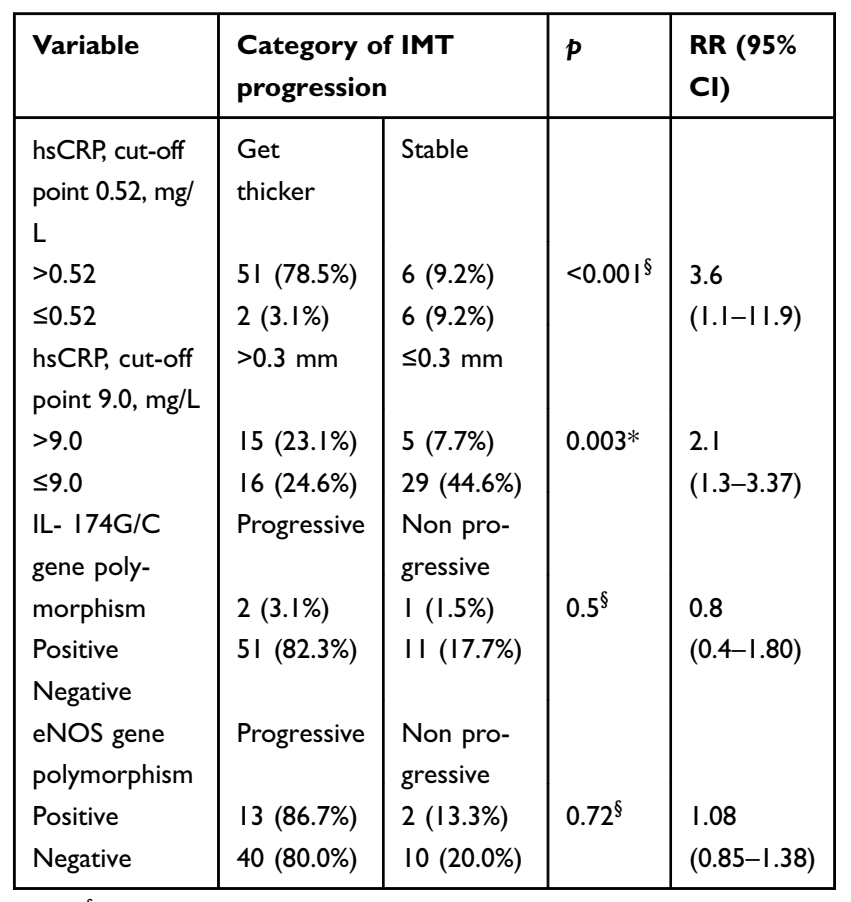

Note: ${ }^{\S}$ Fisher exact test, ${ }^{*}$ Chi-square test.

Abbreviation: IMT, intima-media thickness.

This study showed that hsCRP level was predictive to develop IMT progression on hemodialysis subject. The subject with hsCRP level $>9.00 \mathrm{mg} / \mathrm{L}$ after 6-month dialysis progress to thickening of carotid artery wall of $>0.03 \mathrm{~mm}$. The increasing of carotid IMT is considered a marker of early-onset atherosclerosis, and it seems to predict cardiovascular events in general population. IMT in early-stage CKD patients was related to coronary calcification, but not with the occurrence of cardiovascular events or death. ${ }^{20}$ There was an independent relationship between hsCRP and both IMT as measures of subclinical atherosclerosis. The association between hsCRP and the progression of early carotid atherosclerosis shows sex differences. In further studies analyzing the role of inflammation for cardiovascular diseases and atherosclerosis, these sex differences should be considered. ${ }^{8}$ Both low serum albumin and high hsCRP levels were predictive of CKD for the woman. ${ }^{5}$

IL6 - 174G/C gene polymorphism has an impact on IL6 transcription to increase IL-production. In this study there is 2 subject detected IL6 -174G/C gene polymorphism at IMT progression group. Polymorphism IL -174 G/ $\mathrm{C}$ gene was not significantly predictive of IMT progression at HD subject. This study showed 15 subjects positive of eNOS gene polymorphism, mostly in the IMT progression group. eNOS gene polymorphism has a correlation with low NO level. Several studies confirmed that eNOS gene polymorphism influenced eNOS activity. ${ }^{21,22}$

\section{Conclusion}

The level of hsCRP is a significant predictive of the IMT progression at hemodialysis subject. IL $174 \mathrm{G} / \mathrm{C}$ gene and eNOS gene polymorphism are not significantly predictive of the IMT of progression at hemodialysis subject.

\section{Acknowledgments}

Sincere thanks to directors of Dr. Kariadi Teaching Hospital and Telogerejo Hospital for their support in the patient's management. We would like to thank Prof. Dr Wiguno Projosudjadi, Spesialis Penyakit Dalam (Sp.PD), KGH and Prof Dr Mochamad Sya'bani, Sp.PD, KGH for supervising the research. We would like to thank Dr Hardian, Ph.D. for his help in the statistical analysis. Lastly, we thank all the subjects that participated in this study.

\section{Disclosure}

The authors report no conflicts of interest in this work.

\section{References}

1. Bevc S, Šabić S, Hojs R. Atherosclerosis in hemodialysis patients the role of microinflammation. Ren Fail. 2008;30:1012-1016. doi:10.1080/08860220802406385

2. Nusair MB, Rajpurohit N, Alpert MA. Chronic inflammation and coronary atherosclerosis in patients with end-stage renal disease. Cardiorenal Med. 2012;2:117-124. 000337082

3. Collins AJ, Foley RN, Gilbertson DT, Chen S. United States renal data system public health surveillance of chronic kidney disease and end-stage renal disease. Kidney Int Suppl. 2015;5(1):2-7. doi:10.1038/kisup.2015.2

4. Collins AJ, Foley RN, Gilbertson DT, Chen S. Mortality in the first year of dialysis. J Am Soc Nephrol. 2009;4:5-11. doi:10.2215/ CJN.05980809

5. Kubo S, Kitamura A, Imano H, Cui R, Yamagishi K. Serum albumin and high-sensitivity $\mathrm{C}$-reactive protein are independent risk factors of chronic kidney disease in middle-aged Japanese individuals : the circulatory risk in communities. $J$ Atheroscler Thromb. 2016;23:1089-1098. doi:10.5551/jat.33530 
6. Sander K, Horn CS, Briesenick C, Sander D. High-sensitivity C-reactive protein is independently associated with early carotid artery progression in the INVADE study. Stroke. 2007;38:2881-2886. doi:10.1161/ STROKEAHA.106.481531

7. Horn CS, Poppert RI, Holger H, et al. High-sensitivity C-reactive protein at different stages of atherosclerosis: results of the INVADE study. J Neurol. 2009;256:763. doi:10.1007/s00415-009-5123-5

8. Spoto B, Mattace-Raso F, Sijbrands E, et al. Association of IL-6 and a Functional Polymorphism in the IL-6 Gene with Cardiovascular Events in Patients with CKD. J Am Soc Nephrol. 2015;10 (2):232-243. doi:10.2215/CJN.07000714

9. Mayosi BM, Avery PJ, Baker M, et al. Genotype at the - 174G/C polymorphism of the interleukin- 6 gene is associated with common carotid artery intimal-medial thickness family study and meta-analysis. Stroke. 2005;36:2215-2219. doi:10.1161/01. STR.0000182254.47941.96

10. Stivala F, Mazzarino MC, Malaponte G. Analysis of G(-174) C IL-6 polymorphism and plasma concentrations of inflammatory markers in patients with type 2 diabetes and peripheral arterial disease. J Clin Pathol. 2006;59:211-215. doi:10.1136/jcp.2004.025452

11. Yang Y-M, Huang A, Kaley G, Sun D. eNOS uncoupling and endothelial dysfunction in aged vessels. Am J Physiol Heart Circ Physiol. 2009;297(5):H1829-H1836. doi:10.1152/ajpheart.00230.2009

12. Fatini C, Sofi F, Sticchi E, et al. Influence of eNOS gene polymorphisms on carotid atherosclerosis. Eur J Vasc Endovasc Surg. 2004;27:540-544. doi:10.1016/j.ejvs.2004.02.008

13. Szeto -C-C, Chow K-M, Woo KS, et al. Carotid intima media thickness predicts cardiovascular diseases in chinese predialysis patients with chronic kidney disease. J Am Soc Nephrol. 2007;18 (6):1966-1972. doi:10.1681/ASN.2006101184

14. Szeto C, Chow K, Woo K, Chook P, Ha-Kwan B. Carotid intima media thickness predicts cardiovascular diseases in Chinese pre-dialysis patients with chronic kidney disease. $J$ Am Soc Nephrol. 2007;18:196692. doi:10.1681/ASN.2006101184
15. Liao D, Arnett D, Tyroler H, et al. Arterial stiffness and the development of hypertension. The ARIC study. Hypertension. 1999;34 (2):201-206.

16. Hojs R, Hojs-Fabjan T, Balon BP. Atherosclerosis in patients with end-stage renal failure prior to initiation of hemodialysis. Ren Fail. 2003;25(2):247-254. doi:10.1081/jdi-120018725

17. Patel ML, Radheyshyam VA, Sachan R, Kamal R. Impact of carotid intima-media thickness on long-term outcome in hemodialysis patients. N Am J Med Sci. 2015;7(6):281-287. doi:10.4103/19472714.159339

18. Mihardja L, Soetrisno U, Soegondo S. Prevalence and clinical profile of diabetes mellitus in productive aged urban Indonesians. J Diabetes Invest. 2014;5(5):507-512. doi:10.1111/jdi.12177

19. Prahl U, Wikstrand J, Bergström GM, Behre CJ, Hulthe J, Fagerberg B. We examined whether high-sensitivity C-reactive protein (hsCRP) $\geq 2.0 \mathrm{mg} / \mathrm{L}$ was associated with increased intima-media thickness (IMT), plaque burden, and plaque echolucency in carotid arteries. Women $(n=635)$ from a population sample of a 64-year-old female. Angiology. 2010;61(8):793-801. doi:10.1177/ 0003319710370959

20. Marcos AG, Watanabe R, Lemos MM. Maria eugenia fernandes canziani. Evaluation of intima-media thickness in patients with chronic kidney disease not on dialysis: a prospective study of 24 months. J Bras Nefrol. 2014;36(1):35-41.

21. Paradossi U, Ciofini E, Clerico A, Botto N, Biagini A, Mg C. Endothelial function and carotid intima-media thickness in young healthy subjects among endothelial nitric oxide synthase Glu298 ->3Asp and T-786 ->3C Polymorphisms. Stroke. 2004;1305-1309. doi:10.1161/01.STR.0000126482.86708.37

22. Testa A, Spoto B, Sanguedolce MC, et al. eNOS and caveolin-1 gene polymorphisms interaction and intima-media thickness : a proof of concept study in ESRD patients. Am J Hypertens. 2009;25 (1):103-108. doi:10.1038/ajh.2011.178
International Journal of General Medicine

\section{Publish your work in this journal}

The International Journal of General Medicine is an international, peer-reviewed open-access journal that focuses on general and internal medicine, pathogenesis, epidemiology, diagnosis, monitoring and treatment protocols. The journal is characterized by the rapid reporting of reviews, original research and clinical studies across all disease areas. The manuscript management system is completely online and includes a very quick and fair peer-review system, which is all easy to use. Visit http://www.dovepress.com/ testimonials.php to read real quotes from published authors. 